\title{
INFESTATION RATE OF BRANCHIOBDELLIDS IN AUSTROPOTAMOBIUS PALLIPES ITALICUS FROM A STREAM OF CENTRAL ITALY: PRELIMINARY RESULTS.
}

\author{
F. GHERARDI (1), F. CENNI (1), G. CRUDELE (2), M. MORI (3)
}

(1) Dipartimento di Biologia Animale e Genetica 'Leo Pardi', Università di Firenze, Via Romana 17, 50125 FIRENZE, Italy.

(2) Corpo Forestale dello Stato, Riserve Naturali Casentinesi, Via Dante Alighieri 41, 52015 PRATOVECCHIO, Italy.

(3) Dipartimento per lo Studio del Territorio e delle sue Risorse, Università di Genova, Corso Europa 26, 16132 GENOVA, Italy.

Reçu le 03 janvier 2002

Accepté le 14 octobre 2002

Received 03 January, 2002

Accepted 14 October, 2002

\begin{abstract}
Species identity, infestation rate and distribution over the host body of branchiobdellids (Annelida, Clitellata) have been analysed in an Austropotamobius pallipes italicus population from the National Park of the Foreste Casentinesi, Monte Falterona and Campigna (central Italy). Branchiobdella italica - the nearly unique species present in our samples - did not differ in its occurrence among the size classes of its host, while female crayfish showed a significantly higher infestation rate than the other sex. Branchiobdellids were mostly found on gill chambers and cephalothorax base, and only in the case of larger crayfish and males did they occupy other body areas.
\end{abstract}

Key-words : Austropotamobius pallipes italicus, Branchiobdella italica, epicommensals, branchiobdellids, infestation rate.

\section{TAUX D'INFESTATION DE BRANCHIOBDELLIDES SUR AUSTROPOTAMOBIUS PALLIPES ITALICUS DANS UNE RIVIÈRE DE L'ITALIE CENTRALE : RÉSULTATS PRÉLIMINAIRES.}

\section{RÉSUMÉ}

L'identification des espèces de Branchiobdellides, leur taux d'infestation et leur distribution sur le corps de l'hôte ont été analysés dans une population de Austropotamobius pallipes italicus du Parc National de la Forêt Casentinesi, Monte Falterona et Campigna (Italie centrale). L'espèce Branchiobdella italica - pratiquement 
l'unique présente parmi notre matériel - ne montre pas de différences en relation avec les classes de taille de ses hôtes, mais les femelles ont montré un taux d'infestation significativement plus haut que les mâles. Les branchiobdellides ont surtout été trouvés dans les chambres branchiales et à la base du céphalothorax, et c'est seulement dans le cas des plus grands spécimens et des mâles qu'ils ont été trouvés sur d'autres zones du corps.

Mots-clés: Austropotamobius pallipes italicus, Branchiobdella italica, épicommensales, branchiobdellides, taux d'infestation.

\section{INTRODUCTION}

Several species of leech-like branchiobdellids (Clitellata, Annelida) have been reported as epicommensals adhering to the external surfaces of crayfish (EVANS and EDGERTON, 2001). Literature provides comprehensive descriptions of branchiobdellids epicommensals of crayfish from specific locations or taxonomic groups (HOLT, 1973; SMIETANA and WIERZBICKA, 1999; VOGT, 1999), but a few studies (MORI et al., 2001) attempted to quantify their infestation rate.

A research project carried out to monitor the Austropotamobius pallipes italicus populations in the National Park of the Foreste Casentinesi, Monte Falterona and Campigna (Italy) showed that a number of populations were largely infested by branchiobdellids. Our purposes here were to (1) identify the species of branchiobdellids, (2) evaluate their rate of infestation, and (3) describe their distribution over the crayfish body. Aims (2) and (3) have been achieved through a comparison within the host size and between sexes.

\section{MATERIAL AND METHODS}

The branchiobdellids were sampled from an A. pallipes italicus population living in the stream Fosso della Lama (province of Forlì, Emilia-Romagna, central Italy).

Two 100-m stretches of the stream were inspected at dusk once per day over a week per month between June-August 1999 and 2000. Two capture methods were used; the first, by hand, followed the technique of maximum capture per unit effort (i.e. two researchers captured all the crayfish observed within a fixed time schedule), while the second employed five baited traps located about $25 \mathrm{~m}$ apart. The traps were cylindrical $(80 \mathrm{~cm}$ long and $28 \mathrm{~cm}$ in diameter), covered with polyethylene nets of $4 \times 4 \mathrm{~mm}$ mesh to prevent small crayfish from escaping, and had an inverted cone with the $10-\mathrm{cm}$ wide opening at the two ends.

For each captured specimen we recorded: sex, cephalothorax length (CL), reproductive and moulting states, the number of its epicommensals and their location throughout the crayfish body. From a sample of nine individuals, worms were removed by quickly inserting crayfish into a container with salty water (35 ppt); then branchiobdellids were placed into separate vials. Using the method suggested by GELDER et al. (1994) and MORI et al. (2001), worms were immediately fixed in a $5 \%$ buffered solution of formaldehyde, and then preserved in the laboratory in $70 \%$ ethanol. Species were identified using the key provided by GELDER et al. (1994).

All the other crayfish, at their first capture, were individually marked with numbered plastic tags glued onto the first half of the cephalothorax to prevent the record of the same individual within subsequent samplings. On the basis of their $\mathrm{CL}$, crayfish were 
distinguished into four size classes: class I when $\mathrm{CL} \leq 3 \mathrm{~cm}$, class II when $3 \mathrm{~cm}<\mathrm{CL} \leq 4 \mathrm{~cm}$, class III when $4 \mathrm{~cm}<\mathrm{CL} \leq 5 \mathrm{~cm}$, class IV when $\mathrm{CL}>5 \mathrm{~cm}$. The rate of branchiobdellids infestation was classified into four grades, that is no (NO: no branchiobdellids), low (LO: branchiobdellids less than 100), medium (ME: branchiobdellids 100-200), and high (HI: branchiobdellids more than 200).

To analyse the distribution of branchiobdellids over the crayfish body, we arbitrarily distinguished seven areas, i.e. gill chambers (gc), cephalothorax base (cb), chelipeds (cp), second antennae (an), joint areas (ja), periocular area (pa), and caudal fan (cf) (those areas where the number of branchiobdellids was less than 10 were excluded). We computed the branchiobdellid density as the ratio between the number of the branchiobdellids and the estimated surface in $\mathrm{cm}^{2}$ of the infested area.

Because Wilks test showed no difference either between stream stretches or among periods in all the parameters here measured $(0.507<\mathrm{G}<4.74$, $\mathrm{df}=3)$, data were pooled and collectively analysed. When the scores appeared to be drawn from a normally distributed population after Bartlett's test, parametric statistical techniques were used (ZAR, 1984). Otherwise, statistical inference was made through nonparametric tests (SIEGEL and CASTELLAN, 1988). The level of significance under which the null hypothesis was rejected is $\alpha=0.05$.

\section{RESULTS AND DISCUSSION}

\section{Structure of the crayfish population}

Figure 1 shows the frequency distributions of the two sexes within the four size classes as classified in the Material and Methods section. Males were significantly more represented than the other sex in classes III and IV (Wilks test: $G=105.193$, df $=3$, $P<0.001)$. This result, showing that males reached higher dimensions than the other sex, is in accordance with the structure of other A. pallipes italicus populations from central Italy (GHERARDI et al., 1997; BENVENUTO et al., 2001), and follows the « anomalous » pattern in the terminology of WENNER (1972), which seems the most frequent within crustacean decapods. Only seven (out of a total of 446 crayfish, 1.6\%) presented a soft exoskeleton, while no females were found ovigerous, possibly because these two categories of individuals hide inside shelters and thus were not included into our collections (previous records have shown that ovigerous females occur in the study area at June).

\section{Identity of branchiobdellids}

Out of 636 branchiobdellids identified, 631 were Branchiobdella italica Canegallo, 1929 - the remaining 5 being $B$. exodonta Gruber (1883) - with a percentage of occurrence by the former species per crayfish of $99.4(\mathrm{SE}=0.1, \mathrm{n}=9)$. In Italian inland waters, A. pallipes hosts five species of branchiobdellids (GELDER et al., 1994, 1999). In the U.S., up to six different species have been observed on the body of a single host (HOLT, 1976). The nearly exclusive occurrence of $B$. italica also contrasts in part with data collected from A. pallipes italicus populations of Emilia-Romagna (NOBILE et al., 1995), where, although being more abundant, this species cohabits over the same crayfish with $B$. exodonta and B. parasitica. However, our data are consistent with those reported by MORI et al. (2000) for a population of $A$. pallipes (possibly pallipes) in another Italian region (Liguria). These authors found $B$. italica associated to the most number of individuals, but also observed several $B$. exodonta living inside crayfish branchial chambers. The use of a non-invasive method of collection could explain the nearly absence of this latter worm species in our samples. 


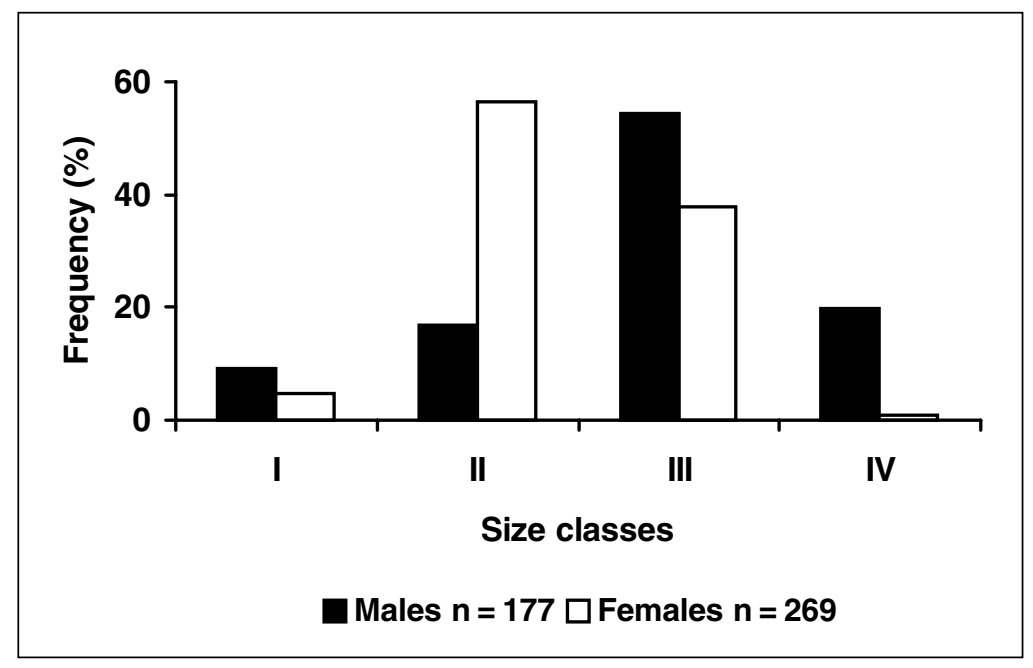

Figure 1

Frequency size distributions of the $A$. pallipes italicus population under study. Size classes are distinguished on the basis of the cephalothorax length (CL); class I $(n=30)$ : $C L \leq 3 \mathrm{~cm}$, class II $(n=182): 3 \mathrm{~cm}<C L \leq 4 \mathrm{~cm}$, class III $(n=198): 4 \mathrm{~cm}<C L \leq 5 \mathrm{~cm}$, class IV $(n=37)$ : CL > $5 \mathrm{~cm}$.

Figure 1

Distribution des fréquences de tailles des populations étudiées de $A$. pallipes italicus. Les classes de taille sont séparées sur la base de la longueur du cephalothorax (CL); classe I $(\mathrm{n}=30): C L \leq 3 \mathrm{~cm}$, classe II $(\mathrm{n}=182): 3 \mathrm{~cm}<\mathrm{CL} \leq 4 \mathrm{~cm}$, classe III $(\mathrm{n}=198)$ : $4 \mathrm{~cm}<\mathrm{CL} \leq 5 \mathrm{~cm}$, classe IV $(\mathrm{n}=37): \mathrm{CL}>5 \mathrm{~cm}$.

\section{Rate of branchiobdellid infestation}

Contrary to Ligurian crayfish populations (MORI et al., 2000), the infestation rate of $B$. italica seemed not to be related to the host size; excluding from the analysis the smallest individuals which were lowly infested, the four grades of infestation as distinguished in the Material and methods section were nearly identical in the classes II, III, and IV (Wilks test: $\mathrm{G}=4.936, \mathrm{df}=6, \mathrm{P}>0.05$ ) (Figure 2). That crayfish smaller than $3 \mathrm{~cm} \mathrm{CL}$ presented a low grade of infestation is probably due to their high frequency of moult (several times a year), while subadults are reported to moult once or twice a year and adult individuals only once (LAURENT, 1988; GHERARDI et al., 1997). More females than males were infested to a high grade (Wilks test: $\mathrm{G}=14.064, \mathrm{df}=3, \mathrm{P}<0.01$ ) (Figure 3 ), possibly because adult females can skip their moulting phase to allocate energy, nutrients, and time to produce eggs (VILLANELLI and GHERARDI, 1998). The above explanations are based on the view that most epicommensals are lost with their host ecdysis.

\section{Branchiobdellid distribution over the crayfish body}

Analysing only those crayfish having a medium grade of infestation, branchiobdellids were distributed differently over their host body (two-way ANOVA: $F=13.71, \mathrm{df}=6 \& 18$, $P<0.01$ ) (Figure 4). After Tukey test, the hierarchy of branchiobdellid density was: $\mathrm{gc}=\mathrm{cb}>>\mathrm{cp}=\mathrm{an}=\mathrm{ja}>\mathrm{pa}=\mathrm{cf}$. Differences were also found among size classes; while the extent of infestation in class IV was similar in the seven areas here examined (at least 2 branchiobdellids per $\mathrm{cm}^{2}$ ), the other classes, but mostly class I, were nearly exclusively infested in gc and cb.

Similarly, the two sexes significantly differed in the density of branchiobdellids in the different areas. A two-way ANOVA showed that, in both sexes, branchiobdellids were more 
often found (and at a similar extent) in gc and $\mathrm{cb}$, but male crayfish presented significantly more branchiobdellids than the females in $\mathrm{cp}$ and an $(F=6.59 \mathrm{df}=6 \& 6, \mathrm{P}<0.05)$ (Figure 5).

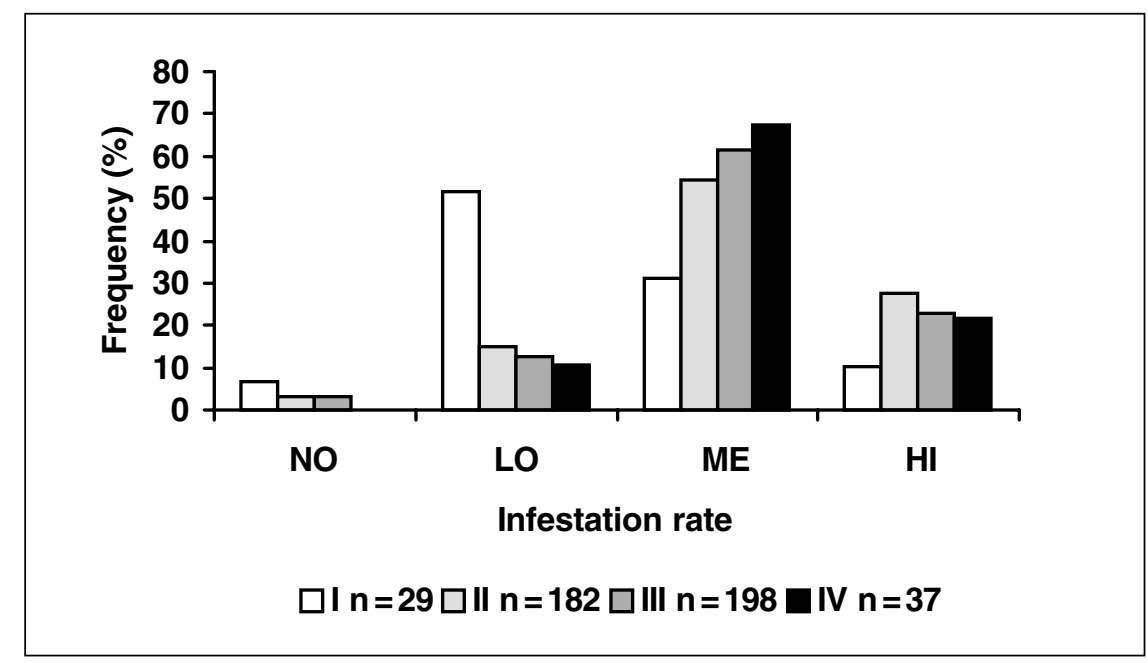

Figure 2

Rate of infestation compared among size classes. We distinguished four grades of infestation, i.e. no (NO: no branchiobdellids), low (LO: branchiobdellids less than 100), medium (ME: branchiobdellids 100-200), and high (HI: branchiobdellids more than 200). See Figure 1 for the classification of size classes.

\section{Figure 2}

Taux d'infestation comparé selon les classes de taille. Nous avons séparé quatre taux d'infestation: nul (NO: pas de branchiobdellides), bas (LO: moins de 100 branchiobdellides), moyen (ME : 100-200 branchiobdellides), haut (HI : plus de 200 branchiobdellides). Voir la Figure 1 pour la classification des classes de taille.

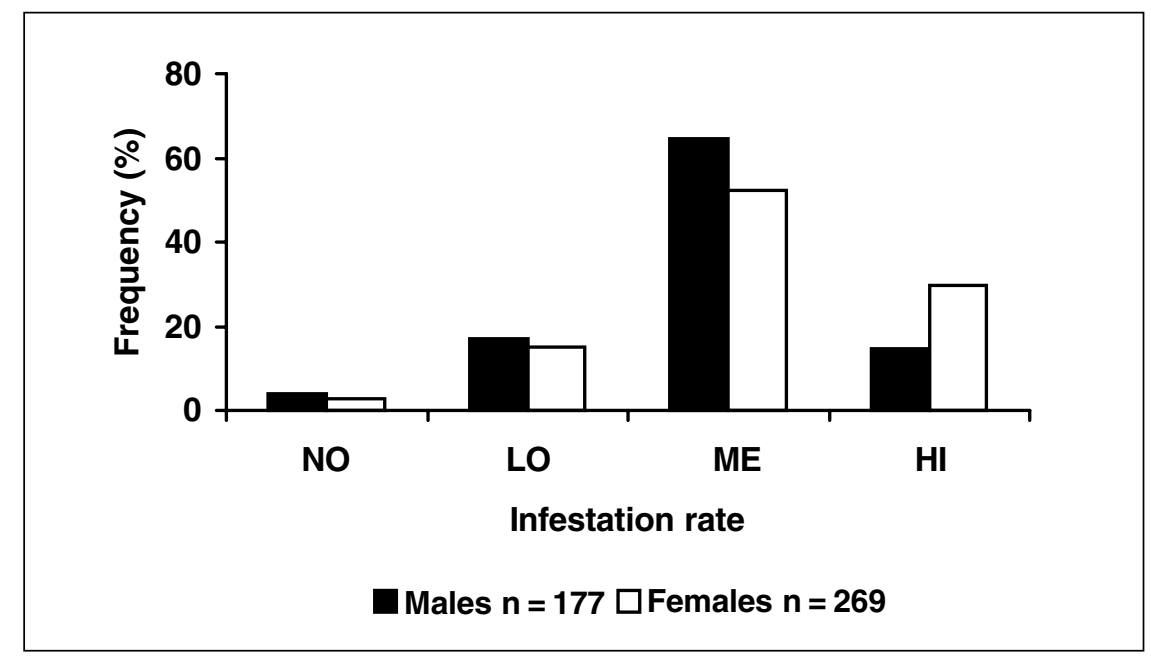

Figure 3

Rate of infestation compared between sexes. See Figure 2 for the explanation of the four grades of infestation.

Figure 3

Comparaison du taux d'infestation parmi les sexes. Voir la Figure 2 pour l'explication des quatre taux d'infestation. 


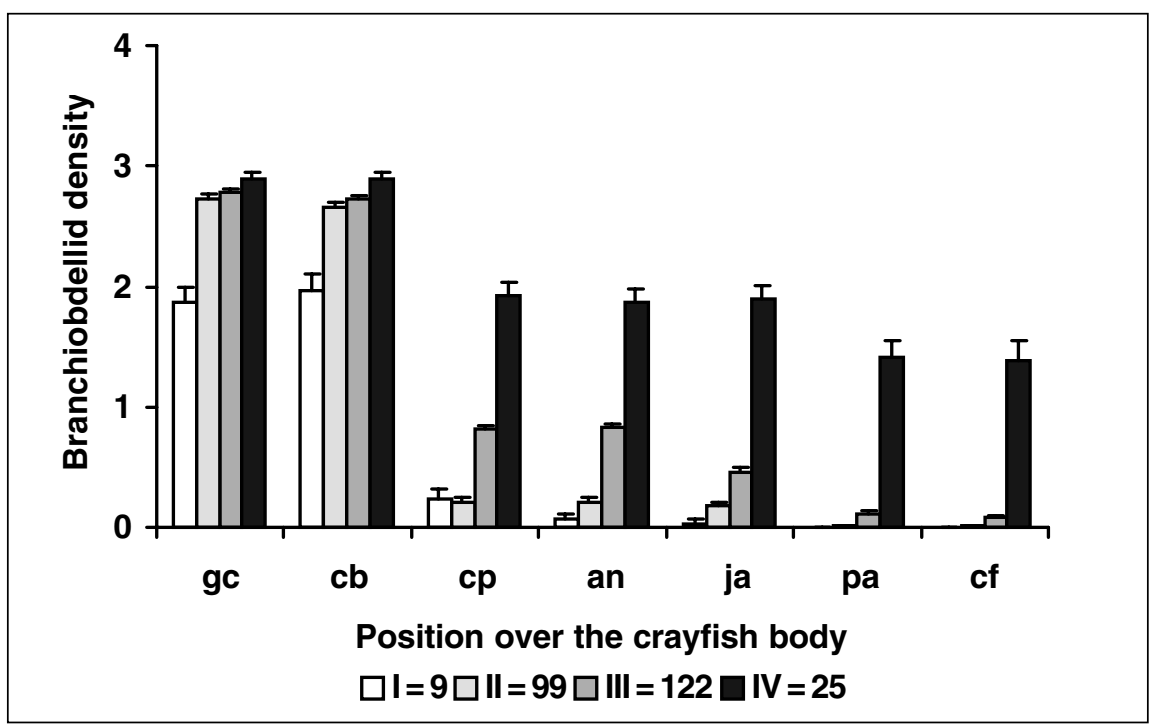

Figure 4

Average branchiobdellid density for infested crayfish (number/cm ${ }^{2}$ ) (+ SE) compared among seven different areas within the body of the host and distinguished among size classes. Areas were: gill chambers (gc), cephalothorax base (cb), chelipeds (cp), second antennae (an), joint areas (ja), periocular area (pa), caudal fan (cf). See Figure 1 for the classification of size classes.

Figure 4

Comparaison de la densité moyenne de branchiobdellides chez les écrevisses infestées $($ nombre/cm $)$ (+ SE) sur sept différentes zones du corps de l'hôte et selon les classes de taille. Les zones sont : chambres branchiales (gc), céphalothorax (cb), chélipèdes (cp), deuxièmes antennes (an), surfaces des articulations (ja), zone périoculaire (pa), éventail caudal (cf). Voir la Figure 1 pour la classification des classes de taille.

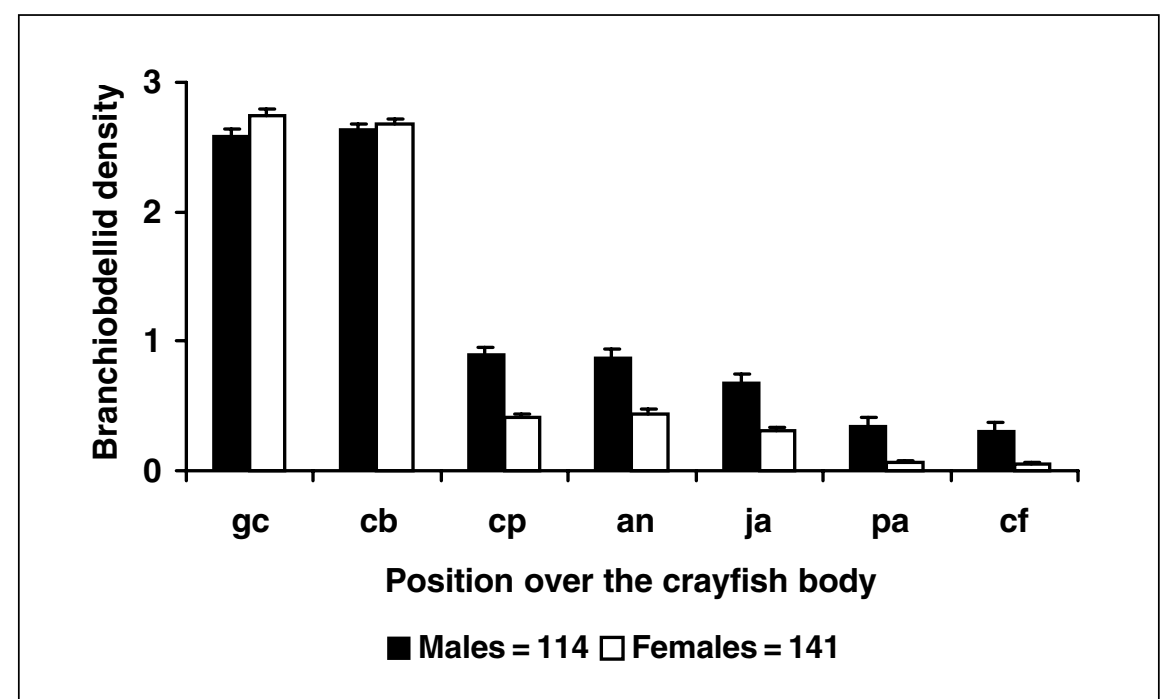

Figure 5

Average branchiobdellid density for infested crayfish (number/cm ${ }^{2}$ ) (+ SE) compared among seven different areas within the body of the host and distinguished between sexes. See Figure 4 for the abbreviations of the areas.

Figure 5

Comparaison de la densité moyenne de branchiobdellides chez les écrevisses infestées

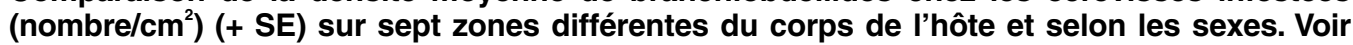
la Figure 4 pour les abréviations des zones du corps. 
Possibly, gill chambers and exoskeleton base offer the worms substrata which are more stable and richer in food. When the more favourable areas become more crowded (and, as a consequence, resource value decreases with the increased competition), newcomers might fare better by opting to settle in the less good, but also less crowded areas (in accordance with the « ideal free distribution » theory; FRETWELL and LUCAS, 1970).

\section{REMARKS}

Although provisional and merely descriptive, our data raise three main questions. First, what is the method of transmission adopted by branchiobdellids when their host moults? There have been a number of reports of branchiobdellids being able to survive without a crayfish host (EVANS and EDGERTON, 2001), but they are not thought to be capable of spending any appreciable length of time living independent of the host (HOLT, 1976). During the moulting period, crayfish are recorded to remain inside their shelters or burrows, cohabiting for several days with the old exoskeleton, until the new exoskeleton has become sufficiently tough (MORI et al., 2001). This behaviour could allow most branchiobdellids to transfer from the old to the new exoskeleton (MAZZARELLI, 1908).

Second, are branchiobdellids commensals or are they real crayfish parasites? Other studies showed that gill damage is common, particularly in cases of heavy infestation (ALDERMAN and POLGLASE, 1988; VOGT, 1999), and evidence of a certain parasitic habit has been obtained for at least $B$. hexodonta, which often feeds on crayfish tissues (GRABDA and WIERZBRICKA, 1969).

And third, the most intriguing question, which are the factors causing the diverse rate of branchiobdellid infestation among populations living in similar habitats and in the same geographic area? Is the infestation rate due to the geographic distribution of branchiobdellid species (GELDER et al., 1994), or does it depend also on other causes, such as pollution (OVERSTREET, 1983), the presence of alien species that could act as vectors (GELDER et al., 1999), and/or the overcrowding of the host populations?

Further researches are clearly needed to provide insight into these main issues that would clarify the nature of the relationship between branchiobdellids and their host crayfish.

\section{ACKNOWLEDGEMENTS}

Our warmest thanks are due to all the staff of the Riserve Naturali Casentinesi, and in particular to Dr Gino Gremoli.

\section{REFERENCES}

ALDERMAN D.J., POLGLASE J.L., 1988. Pathogens, parasites and commensals. In : HOLDICH D.M. and LOWERY R.S. (Eds.), Freshwater crayfish: biology, management and exploitation, Croom Helm, London, 167-212.

BENVENUTO C., CATAUDELLA R., GHERARDI F., PANDOLFI M., BALSAMO M., 2001. Population structure and habitat use of Austropotamobius pallipes in the Monti Sibillini National Park, Italy. Abstract Volume, Knowledge-based Management of European native crayfishes: Dialogues between researchers and managers, Poitiers, September 13-15, 2001, 27. 
EVANS L.H., EDGERTON B.F., 2001. Pathogens, parasites and commensals. In : HOLDICH D.M. (ed.), Biology of freshwater crayfish, Blackwell Science, Oxford, 377-438.

FRETWELL S.D., LUCAS H.L., 1970. On territorial behaviour and other factors influencing habitat distribution in birds. Acta Biotheor., 19, 16-36.

GELDER S.R., DELMASTRO G.B., FERRAGUTI M., 1994. A report on branchiobdellidans (Annelida: Clitellata) and a taxonomic key to the species in northern Italy, including the first record of Cambaricola mesochoreus on the introduced American red swamp crayfish. Boll. Zool., 61, 179-183.

GELDER S.R., DELMASTRO G.B., RAYBURN J.N., 1999. Distribution of native and exotic branchiobdellidans (Annelida: Clitellata) on their respective crayfish hosts in northern Italy, with the first record of native Branchiobdella species on an exotic North American crayfish. J. Limnol., 58, 20-24.

GHERARDI F., VILLANELLI F., DARDI P., 1997. Behavioral ecology of the white-clawed crayfish Austropotamobius pallipes in a Tuscan stream: preliminary results. Freshwater Crayfish, 11, 182-193.

GRABDA E., WIERZBRICKA J., 1969. The problem of parasitism of the species of the genus Branchiobdella Odier, 1823. Polskie Archiwum Hydrobiologii, 16, 93-104.

HOLT P.C., 1973. Epigean branchiobdellids (Annelida: Clitellata) from Florida. Proc. Biol. Soc. Wash., 86, 79-104.

HOLT P.C., 1976. The branchiobdellid (Annelida: Clitellata) associates of Astacoidean crawfishes. Freshwater Crayfish, 2, 337-346.

LAURENT P.J., 1988. Austropotamobius pallipes and A. torrentium, with observations on their interactions with other species in Europe. In: HOLDICH D.M. and LOWERY R.S. (Eds.), Freshwater crayfish: biology, management and exploitation, Croom Helm, London, 341-364.

MAZZARELLI G., 1908. Su alcune malattie di pesci e gamberi osservate in Lombardia. Atti III Congresso Nazionale Pesca Milano, Milano 20 settembre 1906, 261-296.

MORI M., ROSSO E., SALVIDIO S., 2000. Presenza e incidenza delle Branchiobdelle (Annelida, Branchiobdellidae) nelle popolazioni astacicole liguri. Ann. Mus. Civ. St. Nat. Giacomo Doria, Genova, 93, 211-224.

MORI M., PRETONI Y., SALVIDIO S., BALDUZZI A., 2001. Branchiobdellid size-crayfish size: a possible relationship. J. Limnol., 60, 208-210.

NOBILE L., GIANNETTO S., TRENTINI M., CANESTRINI TROTTI G., RESTANI R., 1995. Indagine sulla diffusione di Branchiobdella spp. (Annelida: Branchiobdellidae) in gamberi d'acqua dolce (Austropotamobius pallipes italicus) dell'Appennino toscoemiliano. Boll. Soc. Ital. Patol., 16, 26-33.

OVERSTREET R.M., 1983. Metazoan symbionts of crustaceans. In : PROVENZANO A.J. Jr. (ed.), The biology of Crustacea. Vol. 6, Pathobiology, Academic Press, New York, London, 156-250.

SIEGEL S., CASTELLAN N.J. Jr., 1988. Nonparametric statistics for the behavioral sciences. McGraw-Hill, New York.

SMIETANA P., WIERZBICKA J., 1999. Species of Branchiobdella Odier, 1823 (Annelida: Clitellata) associated with the crayfish Astacus astacus and Astacus leptodactylus in Poland. Freshwater Crayfish, 12, 349-355.

VILLANELLI F., GHERARDI F., 1998. Breeding in the crayfish, Austropotamobius pallipes: mating patterns, mate choice and intermale competition. Freshwater Biol., 40, 305-315.

VOGT G., 1999. Diseases of European freshwater crayfish, with particular emphasis on interspecific transmission of pathogens. In : GHERARDI F. and HOLDICH D.M. (Eds.), Crayfish in Europe as alien species. How to make the best of a bad situation?, Balkema, Rotterdam, 87-103.

WENNER A.M., 1972. Sex ratio as a function of size in marine Crustacea. American Nat., 106, 321-350.

ZAR J.H.,1984. Biostatistical analysis. Prentice-Hall Inc., Englewood Cliffs, New Jersey. 